\title{
UNION FOR THE MEDITERRANEAN: FEATURES OF FUNCTIONING AND PROSPECTS OF DEVELOPMENT
}

\author{
Ivasechko O. Ya., \\ Ph. D in Political Science, \\ Associate Professor of Department of Political Science and International Relations, \\ Lviv Polytechnic National University
}

Khar O. Yu., Ph. D in Political Science, Assistant of Department of Political Science and International Relations, Lviv Polytechnic National University

It has been done the complex study of the functioning and development prospects of the Union for the Mediterranean. Based on the analysis of national and foreign historiography it considers creation and development of organization, its goals and priorities, an attitude to European leaders about the necessity to cooperate with Mediterranean countries. It was found that the Union for the Mediterranean was established in order to support the overall immigration policy, economic and trade development, common law, the environment and common development. The authors emphasize that in order to maintain the viability of the Union for the Mediterranean EU should use more differentiated and thematic approach, which based on security and cooperation, energy agreements, cooperation on food and more targeted financial assistance.

Здійснено комплексне дослідження особливостей функціонування і перспектив розвитку Союзу для Середземномор'я з урахуванням сучасних подій. На основі аналізу вітчизняної та зарубіжної історіографії розглянуто особливості створення організації, іїі цілі та пріоритети, позиції європейських лідерів стосовно необхідності співпраці з середземноморськими країнами. З'ясовано, що метою створення Союзу для Середземномор'я була підтримка загальної імміграційної політики, економічного і торгівельного розвитку, загальних правових норм, захисту навколишнього середовища і спільного розвитку. На думку авторів, для збереження життєздатності Союзу для Середземномор'я ЄС має використовувати більш диференційований і тематичний підхід з акцентом на таких питаннях, як безпека і співробітництво, енергетичні угоди, співпраця з питань харчових продуктів і більш цілеспрямована фінансова допомога.

Осуществлено комплексное исследование особенностей функционирования и перспектив развития Союза для Средиземноморья с учетом современных событий. На основе анализа отечественной и зарубежной историографрии рассмотрены особенности создания организации, ее цели и приоритеты, позиции европейских лидеров о необходимости сотрудничества со средиземноморскими странами. Установлено, что целью создания Союза для Средиземноморья была поддержка общей иммиграционной политики, экономического и торгового развития, общих правовых норм, защиты окружающей среды и совместного развития. По мнению авторов, для сохранения жизнеспособности Союза для Средиземноморья ЕС должен использовать более дифференцированный и тематический подход с акцентом на таких вопросах, как безопасность и сотрудничество, энергетические соглашения, сотрудничество по вопросам пищевых продуктов и более целенаправленная финансовая помощь.

Key words: Union for the Mediterranean, European Union, Sarkozy, the Barcelona Process, EU Regional Policy, European Neighborhood Policy.

Formulation of the problem. The modern international activity of the EU, the cornerstone of which is a policy, is formed on democratic values, and characterizes the active growth and widespread usage of instruments of soft regulatory influence. First of all, we are talking about two important principles: political conditionality and political socialization. The universalist approach of the European Union to the cultural and philosophical category of values is the basis for the spread of democratic standards, legal norms, and practices of the EU (Community achievements). The main purpose of the process of external Europeanization is to extend the European model of governance and outside integration, primarily to neighboring 
countries and regions. In order to ensure its own security and maintain internal stability, the EU tries to expand its influence throughout normalization the political space of neighboring countries according to its own democratic model. The partnership for democracy and overall prosperity with the Mediterranean region is an integral part of the European Neighborhood Policy, which aims to consolidate democracy and development of civil society in the Mediterranean.

The practice of external Europeanization was confirmed when the democratization of the countries of Central and Eastern Europe had been carried out, but the Europeanization of non-European countries with other political, cultural and civilization values is relatively a new phenomenon, which focuses on pragmatic cooperation and the creation of regional projects with these states. The Union's model for the Mediterranean embodies the pragmatism of thinking and distracts from the ideological gap between European and Arabian partners [1, p. 140].

The European concept of relationships between the Mediterranean region during the last 10-15 years has not been almost undergone any changes and is defined not by the principles set out in the treaties, but mostly by the national interests of the certain European countries. The political, social and economic problems of the southern Mediterranean countries continue to be preserved since they rely primarily on foreign investment and aid and to the smallest extent on an independent solution to their problems. Due to this background, the effectiveness of all the Mediterranean initiatives of the EU remained low, and the socio-economic and civilizational differences between these two regions has not decreased. That is why it is extremely important to analyze the peculiarities of the Euro-Mediterranean relations and to determine the prospects of formation the integration association.

The analysis of researches and publications. The theme of the EU's Mediterranean policy is of interest to native and foreign scholars for many years. I. Mokhovaya's works [2] are devoted to problems of the Mediterranean countries' foreign policy evolution and Euro-Mediterranean cooperation. Researcher A. Agapov [3] explores problems and contradictions in the format of relations between the member states of the Union for the Mediterranean. The emphasis on state and regional policy of the initiative for "Union for the Mediterranean" is made by S. Allies [4] in his scientific research. At the same time, the article by V. Lakkina [1], which addresses to the problem of EU policy in the Mediterranean region in the context of the "Arab Spring", is highlighted with an important informative content. However, mostly all the investigations in this area touches upon the issues that have been arisen before the Union for the Mediterranean was formed, while the dynamics of the processes have been taking place since 2008 , necessitates the continuous monitoring of their course. Other researchers $N$ Tatarchuk. [5] and A. Ilyin [6] emphasize the evolution of EU policy regarding the Mediterranean region, as well as France's position on the implementation of the Union for the Mediterranean. Researchers such as O. Sorochinskaya [7] and M. Timofiev [6] highlighted the political and economic aspects of N. Sarkozy's initiative "Union for the Mediterranean", as well as key priorities of implementation. Future scenarios for the development of the "Union for the Mediterranean" were represented in their researches by foreign scholars R. Ayadi [8] and S.Sessa [9]. In addition to that, researchers such as M. Farrell. [10] and A. Galal [11] investigated the effect of the "Arab Spring" on reloading the EU's Mediterranean policy. Scientist Wouters E. [12] has raised the issue of migration policy and human rights protection in the context of the EU's Mediterranean initiative.

The purpose of this article is to elucidate the peculiarities of functioning and future scenarios for the development of the Union for the Mediterranean.

Basic material presentation. The idea of creating a Union for the Mediterranean was presented by French President N. Sarkozy at a rally in Toulon in February 2007 for the first time. Later, N. Sarkozy developed this idea in his speech in Tangier in October of that year in which he appealed to all the countries, having access to the Mediterranean Sea, to join the creation of a political, economic and cultural alliance. "Today, we are going to do for the Mediterranean Union the same thing that was done 60 years ago for the European Union", said the French leader [6]. This statement, which was made during a visit to a number of countries in the Mediterranean basin, immediately caused a wave of criticism. The first one who gave the respond to that was Turkey, emphasizing that it would not take part in the project if it was understood as an alternative to joining the European Union. Moreover, its discontent was expressed by Germany, which saw the threat of EU unity in that project and therefore negatively perceived the idea of participating in a new union only those countries which have access to the Mediterranean Sea. Finally, the European politicians expressed the view that N. Sarkozy, by his own initiative, subverted the Barcelona process. The model was proposed to the Mediterranean countries appealed to the functionality of a similar project,in other words, to solve the most important tasks with the joint efforts. The "pillars" of the project were to become a common immigration policy, economic and trade development, support for common legal norms, environmental protection, and joint development. Collaboration in the functional spheres should later force political rapprochement and the formation of a new "great political structure" [4, p. 66].

The former French President, in his speech in Toulon, noted four key priorities for the new Mediterranean Union. Firstly, it concerned the management of migration flows. N. Sarkozy suggested that the Medi- 
terranean countries should combat illegal immigration, in particular with the help of a convention that will be developed jointly and facilitate the expulsion of illegal immigrants to their motherland. Secondly, among the main directions of the future organization's activity, he stated the solution of environmental problems, spoke in particular for the restoration of the marine ecosystem and the fight against pollution of the Mediterranean Sea. Thirdly, N. Sarkozy stated "joint development" as one of the priorities of the organization, referring to the multilateral cooperation of the Mediterranean countries on a wide range of issues - from education and science to economics and finance. Fourthly, the president mentioned, "the fight against corruption, organized crime, and terrorism" [5, p. 47].

The main purpose of the formation of the Union for the Mediterranean is to involve the countries of the South to the participation and implementation of regional policy. If within the frames of the Barcelona process, the only institution that makes decisions and finances projects is the European Union, the Union for the Mediterranean proposes to set up a co-chair (one representative from the EU and the countries of the South) and to create a joint secretariat to be involved in the selection and analysis of vital projects for the region. The novelty of the union lies in the fact that cooperation within the organization is carried out around specific projects (within defined priority areas) and will become important, but nonetheless, an "additional" chapter of the Barcelona Process.

Thereby an ambitious set of political, economic and humanitarian goals ultimately embodied in a rather limited program of joint actions. Consequently, the following directions of cooperation were proposed for the achievement of the above-mentioned goals:

- the fight against pollution of the Mediterranean Sea;

- development of sea and land transport between the two shores of the Mediterranean Sea;

- joint providing of public safety and prevention of natural and humanitarian catastrophes;

- development of alternative energy sources, solar energy use of the Mediterranean to ensure the long-term development of the region; University;

- development of higher education and joint researches, the creation of the Euro-Mediterranean

- development of micro, small and medium enterprises [2].

The period of 2011, with its numerous revolutions and demonstrations, has become a critical point, appealing to a rethinking of the European Union's policy towards the southern and eastern shores of the Mediterranean, offering various options for Euro-Mediterranean partnership cooperation.

Being aware of need for the right choice of development scenario, in which the future of the Euro-Mediterranean partnership will depend on the readiness of the two regions to cooperate, R. Ayadi and C. Sessa have developed the four scenarios for the development of the future partnership. Each scenario reflects both the perspective of the EU and the Union for the Mediterranean and the various options for the integration of the regions, as well as the further financing of the EU's Mediterranean policy [9, p. 14].

The least optimistic scenario of integration has threatened the prosperity of the Euro-Mediterranean cooperation, prevising the escalating and spreading conflicts, which will increase political uncertainty in the region of the Mediterranean, while economic and social difficulties may become more pronounced. Such uncertainty will inevitably lead to new security problems, which, in turn, will cause rising the waves of illegal migration.

The second tendency is intensified by the continued inertia of the EU, which causes an increase of the gap between the southern and eastern Mediterranean regions. According to such a scenario, EU member states can take a protectionist position and make choices in favor of orientation on the domestic policy. As a result, regional cooperation between the states will cease in the following areas: trade, energy, environment, and education. Financing from the EBRD and the EIB will be stopped. The territory of the southern and eastern Mediterranean can be an area for conflict, rising social tension and poverty. Such a situation can be exploited by terrorist organizations and other radical movements that are active in that region. The second scenario of development may aggravate the confrontation between two regions [9, p. 19].

The third and the most optimistic vision of the evolution of the Euro-Mediterranean partnership involves the integration of the two regions and the creation of the Euro-Mediterranean Union by 2030. Such a scenario is based on the mutual interest of the regions to extend the EU's common policy towards the Mediterranean states and to determine the integration of the Mediterranean region into the EU as a new model of development. Implementation of this approach will be possible through the modernization of the European Neighborhood Instrument to develop a clear strategy for the integration of the Mediterranean into the European Union, which should be completed by 2030. According to this scenario, the elimination of non-tariff barriers to trade and the progressive achievement of comprehensive regulatory harmonization in such areas as technical barriers to trade, sanitary and phytosanitary measures, competition, industrial policy, scientific and technical cooperation, shareholder law, state purchases etc. Such a scenario entails the active participation of the Mediterranean in the European Neighborhood Policy in order to ensure longterm support for the European integration aspirations of the region, owing to that the two-way cooperation 
between the European Union and the Mediterranean will acquire a qualitatively new character. Europe will grant funds to support the reform program, national and regional infrastructure projects. A newly created institution could launch several certain initiatives and become a forum where the member states could be empowered to define a policy of cooperation with other regions.

Finally, the fourth option for cooperation between the EU and the Mediterranean states can characterize future relations between the regions by 2030 . While the previous scenario is based on the EU's readiness to participate in the comprehensive development of cooperation with the Mediterranean, the latter concept involves the unification of Arab countries as the self-sufficient region and the creation of appropriate institutions for lobbying their interests. In future, states will develop cooperation with the EU only in those areas where the two regions have common interests. The regional cooperation within the frameworks of the European Neighborhood Policy will focus on trade, energy, and transport issues, coordinating activities with relevant Union initiatives for the Mediterranean with the participation of the EIB and the EBRD in the region [8, p. 21].

Consequently, to summarize the activities of the organization from its inception to the present stage, today we can only talk about the partial implementation of the Union's projects for the Mediterranean, the most particularly significant of which can be singled out:

1. The opening of the Euro-Mediterranean University in Thessaloniki (Greece) with training in various thematic areas (law, history, politology, renewable energy sources, etc.). The purpose of the establishment of such an educational institution is to facilitate the mobility of students, postgraduates, and professors, as well as to increase employment and implementation of new start-ups. For the realization of the set goal from the budget were allocated about 14,6 million euros.

2. Implementation of the project on promotion of invariable development, consumption and rational use of natural resources, oriented to small and medium-sized enterprises investing in the environmental industry. The project is funded by the European Bank for Reconstruction and Development and focuses primarily on Egypt, Jordan, Morocco, and Tunisia, as well as the Western Balkans and Turkey. This project is a continuation of the positive experience of the Mediterranean Action Plan to support Green Entrepreneurs.

3. Acceptance of the "Mediterranean Sea Basin" program of border cooperation in June 2014 for the 6-years period (2014-2020) is aimed to support new enterprises, technology transfer, as well as commercialization of results in an organized cluster dealing with water and energy resources, waste utilization for better protection of coastal regions of the region. It is funded by the EU, the United Nations and the European Bank for Reconstruction and Development.

4. Realization of the official meetings of Union officials for the Mediterranean in order to make decisions on certain projects. For example, the forum "Mediterranean Water Knowledge Platform" was held in six countries (from Spain to Lebanon). It concerns the improving of water planning and management and creating additional services in this area. In September 2013, a ministerial conference was organized in Paris, attended by representatives from 25 countries. Former President Franz F. Hollande chose to raise the role of women in society via active participation in political, economic and social life. Another example is the verification and certification of its own domestic projects, such as the Tafil Air Park in Jordan, which goal is to reduce the country's energy dependency through the development of renewable energy sources [4, p. 271].

Conclusions. Thus, the changes in the approach to the implementation of the set tasks within the Union for the Mediterranean are characterized by depoliticization and fragmentation. Initiatives, global by nature, are facing at the governmental level with "civilizational" ambitions. As a result, it is clear that there is no economic and commercial basis, and it is not regarding inclusiveness, as noted in the original project of the organization. At the micro-regional level, the Union for the Mediterranean maintains transparency and conscience as opposed to macroregional voluntarism of French diplomacy at an early stage. However, this project continues to depend on the European Neighborhood Policy, through which Brussels provides financial and technical support to the states in the south and east of Europe in spite of regional bodies. The Mediterranean Sea remains an unstable region for the EU, and the Mediterranean Union has not solved the main problem of identifying a specific policy at the level of its resources [10]. Regional infrastructure projects can become part of the new Union's policy for the Mediterranean. The fundamental principle in this process should be "convergence", but not accession, association or neighborhood.

Nowadays the European Union is experiencing difficulties within the association and is forced to fight the migration crisis and finance the southern states to overcome the economic crisis. Despite the fact that the EU has the most comprehensive and multidimensional set of policy tools, there is still a lack of sufficient leverage to stabilize the situation in the Arab countries. In order for the EU-Mediterranean relationship to become qualitatively new and bring only positive effects from such a partnership, the EU needs to develop a new approach to the Mediterranean policy. It should be based on differentiated and, at the same time, common strategic interests of both parts, and not on the aspiring to find out the "common values" of the European Neighborhood Policy. Therefore, the EU should become more flexible in the way how it defines individual approaches for implementing bilateral cooperation projects. 
To achieve the goals set by the Union for the Mediterranean, the EU should use a more differentiated and thematic approach with emphasis on issues such as security and cooperation, energy agreements, food cooperation and financial assistance should be more focused. EU Public Consultation is a good and more inclusive start to discuss the most pressing issues of political life and to coordinate the interests of the stakeholders in the region.

\section{References:}

1. Латкина В. Политика Европейского союза в средиземноморье в контексте «арабской весны». Вестник МГИМО Университ. 2014. № 2. С. 139-149.

2. Мохова И. Французская инициатива Средиземноморского Союза. Институт Ближнего Востока. 2008. URL: http://www.iimes.ru/?p=7456 (дата звернення: 19.04.2018).

3. Агапов А. «Союз для Средиземноморья»: проблемы и противоречия. Мировая экономика и международные отношения. 2010. № 9. С. 66-71.

4. Алльес П. Союз Средиземноморья: государственная и региональная политика. Известия Иркутской государственной экономической академии. 2016. № 2. С. 266-273.

5. Татарчук Н. Эволюция идеи Н. Саркози о создании Средиземноморского союза: от тулонской речи к «Римскому воззванию». Международные отношения и мировая политика. 2010. No 1. C. 47.

6. Тимофеев М. создании Союза для Средиземноморья: политические и экономические аспекты. Портал «Родон». 2008. URL: http://www.rodon.org/polit-080729104252 (дата звернення: 21.04.2018).

7. Сорочинська О. «Союз для Середземномор'я»: пріоритети та реалізація. Міжнародні відносини і туризм: сучасність та ретроспектива: збірник матеріалів Першої міжнародної науково-практичної конференції студентів та молодих вчених. 2013. С. 199-202.

8. Ayadi R., Gadi S. The Euro-Mediterranean Partnership and Development Assistance: Past Trends and Future Scenarios. MEDPRO Technical Report. 2013. No 32. C. 19-21.

9. Sessa C., Ayadi R. What scenarios for the Euro-Mediterranean in 2030 in the wake of the Arab spring? CIHEAM. 2013. No 71. C. 13-17.

10. Farrell M. Bridging the Gap between EU, Mediterranean and Africa relations: Partnership, Governance and $(\mathrm{Re})$-evolving Relations. Centre international de formation européenne. 2010. No 2. C. 181-182.

11. Galal A. Rethinking the EU's Mediterranean policy after the Arab Spring. Europesworld. 2015. URL: http://europesworld.org/2015/11/12/rethinking-the-eus-mediterranean-policy-after-the-arab-spring/\#. WSIOBuvyjIU (дата звернення: 17.04.2018).

12. Wauters E., Cogolati S. Crossing the Mediterranean Sea: EU Migration Policies and Human Rights. Brill. 2017. C. 9-11. 